\title{
Asopos and his Multiple Daughters: Traces of Preclassical Epic in the Aeginetan Odes of Pindar
}

\section{Citation}

Nagy, Gregory. 2010. Asopos and His Multiple Daughters: Traces of Preclassical Epic in the Aeginetan Odes of Pindar. In Aegina: Contexts for Choral Lyric Poetry, ed. David Fearn: 40-78. Oxford: Oxford University Press.

\section{Published Version}

10.1093/acprof:oso/9780199546510.003.0002

\section{Permanent link}

http://nrs.harvard.edu/urn-3:HUL.InstRepos:15479858

\section{Terms of Use}

This article was downloaded from Harvard University's DASH repository, and is made available under the terms and conditions applicable to Other Posted Material, as set forth at http:// nrs.harvard.edu/urn-3:HUL.InstRepos:dash.current.terms-of-use\#LAA

\section{Share Your Story}

The Harvard community has made this article openly available.

Please share how this access benefits you. Submit a story.

Accessibility 


\section{Asopos and his multiple daughters: Traces of preclassical epic in the Aeginetan Odes of Pindar \\ Gregory Nagy}

This is an electronic version of Chapter 1 of Aegina: Contexts for Choral Lyric Poetry. Myth, History, and Identity in the Fifth Century BC (ed. David Fearn; Oxford 2011) 41-78. The original pagination of the chapter will be indicated in this electronic version by way of double-square brackets ("[[" and "]]"). For example, “[[41|42]]" indicates where p. 41 of the printed chapter ends and p. 42 begins.

\section{Introduction}

The Aeginetan odes of Pindar show traces of a preclassical phase of epic. By "preclassical" I mean a phase that predates the reception of Homeric poetry in Athens during the classical period of the fifth century BCE. A clear sign of such preclassical epic, I argue, is a pattern of coexistence between Homeric and Hesiodic poetry. I will concentrate on one particular aspect of this coexistence, involving myths about the river god Asopos and his daughters.

In two books about the reception of Homer, Homer the Classic (online edition 2008; printed edition 2009) and Homer the Preclassic (online edition 2009; printed edition 2010), I reconstruct two distinct phases of epic poetry as performed in a particular setting. ${ }^{1}$ That setting was the seasonally recurring festival of the Panathenaia in Athens. One of the two phases of epic as performed at the Panathenaia was the "classical" period of the fifth century BCE. In this phase, epic was understood to be the Iliad and Odyssey as we know them, attributed to Homer. The other phase was a "preclassical" period dating back to the era of the Peisistratidai, a dynasty of tyrants who [[41|42]] ruled Athens in the sixth century BCE. As I argue in Homer the Preclassic,

\footnotetext{
${ }^{1}$ Nagy 2008/2009, 2009/2010.
} 
two features of this preclassical epic distinguished it from its classical counterpart. First, the Homer of the sixth century was understood to be the poet of not only the Iliad and Odyssey but also of other epics collectively known as the epic Cycle. Second, the epic poetry attributed to this preclassical Homer coexisted with epic poetry attributed to other poets, especially to Hesiod. In other words, the epics performed at the Panathenaia in the sixth century BCE included not only the epics attributed to Homer but also epics attributed to rival figures like Hesiod. ${ }^{2}$ Such a coexistence between Homeric and Hesiodic poetry in the sixth century became obsolete in the fifth. By the time of the fifth century, as I argue in Homer the Classic, only the Iliad and Odyssey were performed at the Panathenaia, and only these two epics were attributed to Homer. To be contrasted is the preclassical version of Homer, which coexisted with Hesiod at the Panathenaia. In the preclassical period of epic as performed in Athens, Homer had still shared the stage, as it were, with Hesiod.

In the poetry of Pindar, we can find traces of such a preclassical Homer, and I analyzed these traces in a book entitled Pindar's Homer. ${ }^{3}$ In that book, I concentrated on Pindar's use of epic themes he attributed to Homer as the poet of the Cycle. In this presentation, I concentrate on his use of epic themes he attributed to Hesiod. These themes, as we will see, are not incompatible with Homer. In other words, Pindar's Hesiod is compatible with Pindar's Homer.

One Hesiodic text stands out: it is the Catalogue of Women, or the Ehoiai. This text represents an epic tradition linked directly to the Hesiodic Theogony. The beginning of the Catalogue, Hesiod F 1, was designed as a continuation of the narrative that leaves off at verse 1020 of the

\footnotetext{
${ }^{2}$ Traces of such a coexistence between the preclassical Homer and Hesiod are evident in the pseudo-Herodotean Life of Homer and in the Contest of Homer and Hesiod, conventionally known as the Certamen. See Nagy 2004b; also Nagy 2009/2010 I§\$171-177.

${ }^{3}$ Nagy 1990a.
} 
Theogony, while verses 1019-1020 of the Theogony were designed as a transition into the narrative that begins with the Catalogue.

What I just formulated about the link between the narratives of the Hesiodic Theogony and the Hesiodic Catalogue is in general agreement [[42|43]] with the formulation of Martin West in his book on the Hesiodic Catalogue, ${ }^{4}$ except that I disagree with West when he says that the Theogony and the Catalogue were composed by different individual poets and that "our poet [that is, the poet of the Catalogue] rewrote the end of Hesiod's Theogony in his own style." $\mathrm{My}$ view is that the continuity of narration in the transition from Theogony to Catalogue is an aspect of the same oral traditions that resulted in the texts that we know as the Theogony and Catalogue. It is also my view that the composition of Hesiodic poetry cannot be divorced from the reception of that poetry in the sixth century BCE.

West argues that the epic text of the Catalogue was composed in Athens sometime between 580 and 520 BCE and, "if the addition of [Theogony] 965-1020 was contemporary, the range may perhaps be narrowed to [around] 540-520 [BCE]." ${ }^{6}$ The broader and the narrower time-frames, (1) 580-520 and (2) 540-520, are based on dating criteria linked respectively to (1) the contents of the Catalogue and (2) the contents of verses 965-1020 of the Theogony. From West's point of view, the Hesiodic Catalogue was composed in Athens as a text to be added to the text of the Theogony.

I agree, but I add a qualification: this overall text of Hesiod, as reconstructed by West, resulted from the reception of living oral traditions. These traditions cannot be viewed exclusively on a synchronic level, as if they resulted in individualized poetic compositions.

\footnotetext{
${ }^{4}$ West 1985:126.

${ }^{5}$ West 1985:167.

${ }^{6}$ West 1985:136.
} 
That is because the actual process of composition was a matter of ongoing recomposition-inperformance, and such a process needs to be viewed diachronically as well as synchronically. ${ }^{7}$

With this qualification in place, I offer a reformulation of the relationship between the Hesiodic Theogony and Catalogue. From my point of view, the narrative of the Catalogue was performed in Athens as an organic continuation of the narrative of the Theogony. And the venue for such a performance, in my view, was the festival of the Panathenaia at Athens in the era of the Peisistratidai. The time frame of 540-520 BCE, which is the dating assigned by West to the transitional verses 965-1024 of the Theogony, neatly matches that era. [[43|44]]

Testing this reformulation, I will now proceed to analyze the myths about the river god

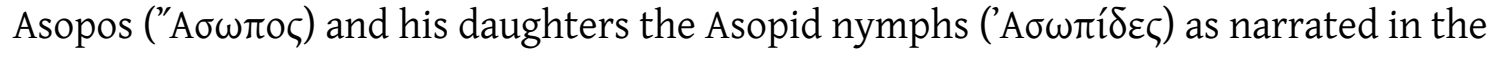
Hesiodic Catalogue. What I will argue is that these myths accommodate the political ideology of Athens in the era that corresponds to the time frame of 540-520 BCE. And that time frame corresponds to a preclassical era when Homeric and Hesiodic poetry still coexisted at the Panathenaia.

\section{Aegina, daughter of Asopos}

According to West's reconstruction of the Hesiodic Catalogue of Women, the overall narrative about the nymphs who were daughters of Asopos took place in Scroll 4, and this narrative followed basically the same sequence we see in the Bibliotheke of "pseudo-" Apollodorus" (3.12.6-3.13.8), where the descendants of Asopos are listed after the descendants of Atlas and before the Attic heroes. ${ }^{8}$

\footnotetext{
${ }^{7}$ On the distinction between synchronic and diachronic approaches to the analysis of a given structure in the study of oral poetics, I refer to my observations in Nagy 2003:1.

${ }^{8}$ West 1985:91. Hereafter, I will refer to the author of the Bibliotheke simply as "Apollodorus," understanding that he is not Apollodorus of Athens. For citations of Apollodorus, I use the numbering to be found in the translation and commentary of Frazer 1921 (who uses a text based on the edition of Wagner 1894).
} 
I concentrate on one particular daughter of the river god Asopos: she is a local goddess or nymph called Aegina (Aï $ү ı v \alpha)$, who is the mother of Aiakos (Aixkóc), the native hero of the island that is likewise called Aegina (Aî́pvo $)$. The basic narrative is retold in Pindar's Isthmian 8 (lines 16-31), an Aeginetan ode celebrating the victory of an Aeginetan athlete at the Isthmian festival of $478 \mathrm{BCE}$. According to Pindar's retelling, the nymph Aegina is the twin sister of a nymph named Thebe $(\Theta \dot{n} \beta \eta / \Theta \eta ́ n \alpha)$, local goddess of Thebes $(\Theta \tilde{\eta} \beta \alpha \mathrm{l})$ in Boeotia. The name of this sister nymph is significant, since the name of the place that is Thebes $\left(\Theta \tilde{\eta} \beta \alpha_{l}\right)$ is the elliptic plural of the name of the nymph that is Thebe $\left(\Theta \ominus^{\prime} \beta \eta / \Theta \eta^{\prime} \beta \alpha\right) .{ }^{9}$ According to the narrative of this Aeginetan ode of Pindar, Aegina and Thebe are twin nymphs, the youngest of the daughters of Asopos, who is the god of the river Asopos that waters the land of [[44|45]] Thebes. The myth tells how Zeus took Aegina away from this land and relocated her in another land. This other land, in Pindar's retelling, was an island once known as Oinōnē, which was thereafter renamed as Aegina. And it is here in Aegina that Zeus impregnated Aegina, who gave birth to Aiakos. So goes the myth as retold in Pindar's Isthmian 8.

It is important to note that Aiakos was worshipped by the population of Aegina as their primary local cult hero. Pausanias gives a detailed description of the sacred space of worship, called the Aiakeion, featuring a bōmos 'altar' that supposedly contained the corpse of Aiakos (2.29.6-8). There is a reference to this Aiakeion in Pindar's Nemean 5 (53-54), where a ritual command is made to offer garlands of blossoms at this place sacred to Aiakos. ${ }^{10}$

As I will now argue, the myth of this cult hero Aiakos as retold in Pindar's Isthmian 8 is relevant not only to the political ideology of the state of Aegina in the early fifth century BCE.

\footnotetext{
${ }^{9}$ Nagy 2004a:163.

${ }^{10}$ On the hero cult of Aiakos as worshipped in Aegina, see Fearn 2007:89-90. See also his pp. 90-93 for evidence indicating that both this cult of Aiakos and the corpse allegedly belonging to Aiakos were eventually relocated in Athens. A most telling piece of relevant evidence is provided by Herodotus (5.89).
} 
It is relevant also to the political ideology of the state of Athens - in an even earlier period that corresponds to the time frame of the Hesiodic Catalogue. That earlier period, as I will also argue, was a time when Athens and Aegina were not yet enemies.

\section{Aegina, mother of Aiakos and his descendants}

The idea that Zeus impregnated the nymph Aegina in the land of Aegina, where she gave birth to Aiakos, is no invention by Pindar. The same idea is evident in the Hesiodic Catalogue (Hesiod F 205), where we find the same elements of the myth. The Hesiodic narrative goes on to say that Aiakos, growing up and reaching adolescence in Aegina (F 205 line 2), was all alone

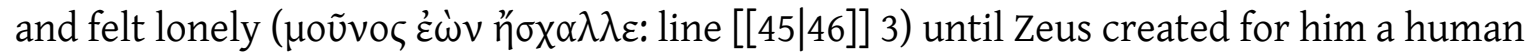
population, the Myrmidons, by way of transforming the local ants into men and women:

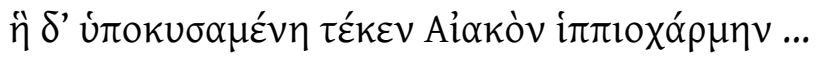

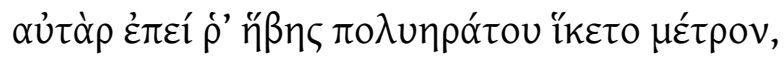

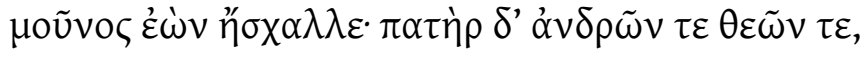

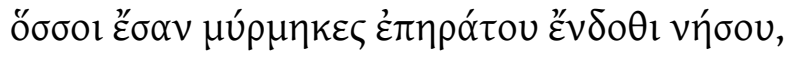

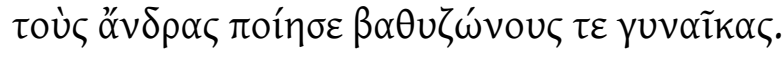
oî $\delta$

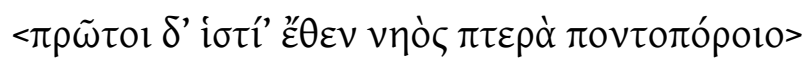
She [= Aegina] got pregnant [by Zeus] and gave birth to Aiakos, who delights in the art of charioteering, but when he reached the stage of adolescence, which comes with so much delight in love, he was alone and felt troubled. Then the father of men and gods took all the ants that were there on that island so full of delight, and he made them into men and also women with low-slung waistbands, 
and these humans, I can now say, ${ }^{11}$ were the first to fit together ships, which are curved at both ends, and they were the first to make sails, which become wings for a ship as it makes its way through the watery divide.

Hesiod F 205

via Scholia for Pindar Nemean 3.21

\section{Aeginetan anthropogony}

In the poetics of this myth as retold in the Hesiodic narrative, we see a variety of details that are linked with the politics of Aegina. ${ }^{12}$ I draw attention here to one detail in particular, concerning anthropogony. In using this term anthropogony, I have in mind myths concerning the genesis of humans. As we take a closer look at the Hesiodic narrative, we can see two levels of anthropogony. On one level, the hero Aiakos originates from Aegina the nymph, who is his mother. On another level, the people of this hero's native land originate from Aegina the island, which is their Mother Earth. In the case of Aiakos, his origin from [[46|47]] Aegina is visualized as a birth from a local goddess or nymph. In the case of the rest of the Aeginetans, their origin is visualized as a transformation from ants generated from the earth. The identity of Aegina as a nymph converges with the identity of Aegina as a land that becomes the localized Mother Earth of the native population.

In an Aeginetan ode by Pindar, Pythian 8 (produced in $446 \mathrm{BCE}$, according the Pindaric scholia), the nymph Aegina is actually invoked as the beloved Mother of the population:

\footnotetext{
${ }^{11}$ The particle $\delta \eta$ here has an "evidentiary" force, indicating that the speaker has just seen something, in other words, that the speaker has achieved an insight just a moment ago ('aha, now I see that...'). See Bakker 1997:74-80, 2005:146.

${ }^{12}$ Fearn 2007:101-102.
} 


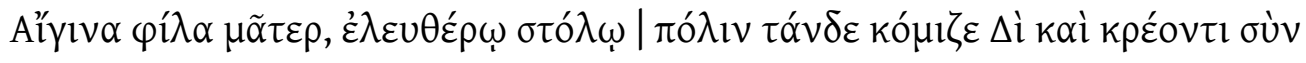

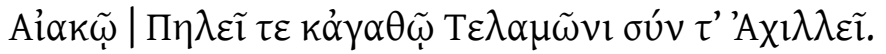

Aegina! Mother near and dear $!^{13}$ Make a (naval) mission [stolos] of freedom ${ }^{14}$ for this polis [= the city state of Aegina] as you bring it back to safety, back to Zeus! ${ }^{15}$ May it happen with the help of Aiakos the Ruler. And of Peleus. And of noble Telamon. And especially of Achilles.

Pindar Pythian 8.98-100

\section{Aeginetan thalassocracy}

As I will now argue, this reverent invocation of Mother Aegina is a pointed reference to the glorious past of the island state of Aegina as a major maritime power in the Mediterranean world. And this reference has to do with the concept of an eleutheros stolos, that is, 'a mission of freedom', which is made possible by the otherworldly help [[47|48]] of the hero Aiakos and of his descendants, namely Peleus, Telamon, and Achilles.

In making this argument, I start by highlighting a detail in the passage of the Hesiodic Catalogue that pictures the Aeginetans as the descendants of an autochthonous population generated from the Mother Earth that is Aegina: that same passage also pictures these autochthonous people of Aegina as the world's first ship-builders and navigators (F 205). As we

\footnotetext{
${ }^{13}$ See also Pindar Nemean 5 (line 8): in this Aeginetan ode, Aegina is described as mātropolis 'mother city'.

${ }^{14}$ My translation of eletheros stolos as 'a (naval) mission of freedom' is based on an interpretation that I will develop as my argumentation proceeds.

${ }^{15}$ On the usage of komizein in the sense of 'restoring' or even 'rescuing' something precious and sacred, see Nagy 2001:152-155 (with notes 13 and 22). In a future project, I study the mystical sense of the verb komizein as 'bringing back to light and life', associated with the noun nostos in the mystical sense of 'coming back to light and life' (on which see Nagy 1990b:218-29, following Frame 1978). In that project, I hope to show the link between such a mystical sense of komizein in Pindar's Pythian 8 (line 99: kó $\mu \iota \zeta \varepsilon)$ ) and the context of aiōn (line 97: aíwv) in the sense of an eternally recycling and luminous 'life-force'. Most useful for my project will be the holistic analysis of Pythian 8 by Martin 2004.
} 
will now see, this linking of the autochthonous descent of the Aeginetans with their maritime way of life is essential for understanding the concept of an eleutheros stolos, that is, 'a (naval) mission of freedom', as it relates to Aiakos and his descendants.

We know for a fact that the economic and military prestige of the Aeginetans stemmed from their history as a maritime people. ${ }^{16}$ Strabo $(8.6 .16$ C 375$)$ says it most succinctly when he

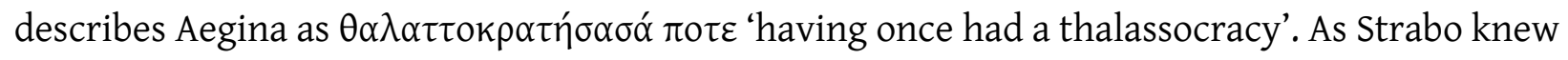
well, the maritime power of the state of Aegina, as expressed by the term 'thalassocracy', was ultimately eliminated by the rival state of Athens, which developed a 'thalassocracy' of its own. We recall the memorable reference to Athenian maritime power as a 'thalassocracy' in the work of Thucydides (1.4).

By the time when Pindar composed the Aeginetan ode that we know as Pythian 8 (446 BCE), the maritime power of Aegina was a thing of the past, since the island had already become a satellite of Athens. ${ }^{17}$ So, in terms of my argument, the fleeting reference to an eleutheros stolos, that is, to 'a (naval) mission of freedom' in Pindar's Aeginetan ode, can be taken as a nostalgic evocation of the island's glorious maritime past - before the onset of the political realities that prevailed by the time of Pindar's Pythian 8. But the point is, the glorious past of the Aeginetans as a seafaring people is relevant to their myths about their origins. And these myths, as we are about to see, are relevant to the wording of Pindar concerning the stolos 'mission' connected with the otherworldly help of Aiakos and his descendants in Pythian 8. [[48|49]]

\section{Aiakos and the Aiakidai}

The linking of Aiakos and his descendants with the prestige of the Aeginetans as a maritime power is most evident in a narrative of Herodotus (8.40-97) about the military

\footnotetext{
${ }^{16}$ Figueira 1993.

${ }^{17}$ On the subjugation of Aegina by Athens in 457 BCE, see Fearn 2007:91.
} 
success of the Aeginetans in 480 BCE, on the occasion of the naval battle of Salamis in the Persian War. This narrative highlights the role of the hero Aiakos and his heroic descendants, the Aiakidai, as otherworldly helpers of the Hellenes in their struggle against the Persians (8.64 and 8.83-84). Before the naval battle at Salamis, according to this narrative, the combined

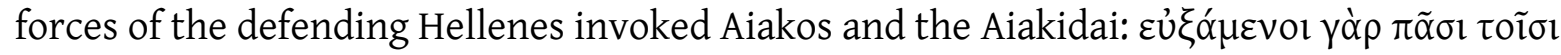

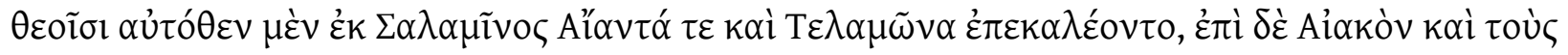

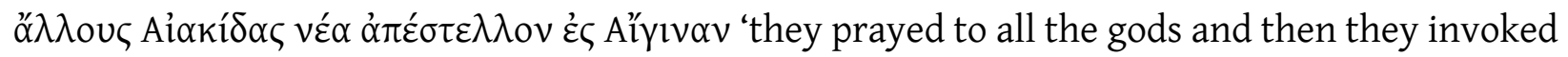
[epi-kaleîsthai] Ajax and Telamon to come from right there [autothen], from Salamis, but they sent for Aiakos and the other Aiakidai to come (from Aegina), sending on a (naval) mission [apo-stellein] a ship to Aegina' (8.64.2). When the ship bringing 'Aiakos and the other Aiakidai' from Aegina to Salamis finally arrived at Salamis, it figured most prominently in the successful naval battle there - according to the Aeginetans but not according to the Athenians (Herodotus 8.84.2). In one of Pindar's Aeginetan odes, Isthmian 5 (line 48), there is an overt reference to the military success of the Aeginetan fleet at the battle of Salamis.

The verb used by Herodotus in referring to the naval mission involving Aiakos and the Aiakidai, apo-stellein 'send on a naval mission', corresponds to the noun stolos '(naval) mission' as used by Pindar in Pythian 8. Embedded in that ode is a prayer that calls for a new mission

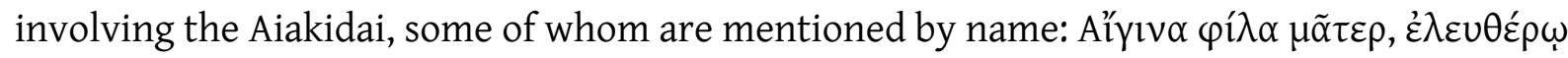

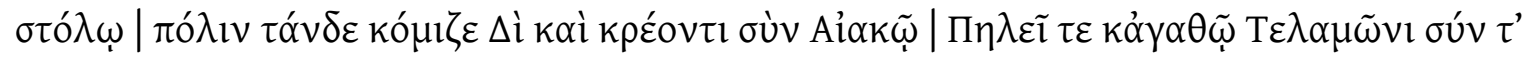
'Axı $\lambda \lambda \varepsilon \tilde{\varepsilon}$ 'Aegina! Mother near and dear! Make a (naval) mission [stolos] of freedom for this polis [= the island state of Aegina] as you bring it back to safety, back to Zeus! May it happen with the help of Aiakos the Ruler. And of Peleus. And of noble Telamon. And especially of Achilles' (Pindar Pythian 8.98-100). In term of my argumentation, Pindar's wording alludes nostalgically to the glory days when an [[49|50]] Aeginetan ship was sent back to Aegina on a mission to 
bring Aiakos and the Aiakidai to Salamis so that they may save the Hellenes in the naval battle there, thus freeing Hellas - including Aegina - from the tyranny of the Persian invaders. For a parallel usage of stolos as 'naval mission' I cite the wording of Sophocles in his Philoctetes (243-

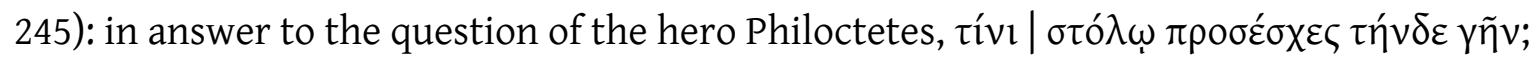
$\pi o ́ \theta \varepsilon v \pi \lambda \varepsilon^{\prime} \omega v$; 'on what naval mission [stolos] have you sailed and docked your ship in this land, and sailing from where?' (243-244), the hero Neoptolemos answers, $\bar{\varepsilon} \xi$ 'I $\lambda$ íou $\tau$ $v \alpha v \sigma \tau 0 \lambda \tilde{\omega}$ 'As of this moment, I am on a naval mission [nau-stoleîn] from Troy' (245). ${ }^{18}$

In an earlier work on Pindar's references to Aiakos and the Aiakidai in his Aeginetan odes, I analyzed at some length the relevance of the narrative of Herodotus concerning the Aeginetan ship that was sent on a mission to bring Aiakos and the Aiakidai to the naval battle of Salamis (8.64.2). ${ }^{19}$ Here I confine myself to some basic observations stemming from my analysis in that work.

I start with a question: how exactly are we to imagine an ensemble of 'Aiakos and the Aiakidai', transported by ship from Aegina to Salamis? The conventional explanation is that 'Aiakos and the Aiakidai' were simulacra of the heroes, or maybe even their relics. ${ }^{20}$ But there is no way of being certain about such an explanation. The only certainty is that the presence of 'Aiakos and the Aiakidai' was thought to be a reality, and that this presence, however it was imagined by the Aeginetans, could actually be transported from Aegina to Salamis. I highlight the theme of mobility here: the ensemble of 'Aiakos and the Aiakidai' was evidently thought to be movable, mobile. It was thought that this ensemble could be moved from a safe place to an unsafe place where their help was needed. In this line of thinking, there must have been some kind of a ritual connection between the ensemble of 'Aiakos and the Aiakidai' on the one hand

\footnotetext{
${ }^{18}$ Comparable is nau-stolein in an Aeginetan ode of Pindar, Nemean 6 (line 32).

${ }^{19}$ Nagy 1990a:175-178 (6§§56-58), with citations.

${ }^{20}$ Nagy 1990a:176-177 (6\$57). For an impartial discussion, see Fearn 2007:95-96n29.
} 
and, on the other hand, the land of Aegina. Or, to put it another way, there must have been some kind of a ritual connection between these native sons and their native Mother Earth. $[[50 \mid 51]]$

I propose to describe this way of thinking as a sacralized metonymy. For a working definition of metonymy here, I mean an expression of meaning by way of connection, as opposed to metaphor, by which I mean an expression of meaning by way of substitution. ${ }^{21}$

I return to the question: how exactly are we to imagine an ensemble of 'Aiakos and the Aiakidai', transported by ship from Aegina to Salamis in the narrative of Herodotus (8.64.2)? The wording of Pindar's Pythian 8, the Aeginetan ode that I cited earlier, may hold an answer. Besides Aiakos himself, I think that the unnamed ensemble of Aiakidai in the narrative of Herodotus included Telamon, Peleus, and Achilles. All three of these heroes are invoked by name in Pindar's Pythian 8. And I also think that Ajax, though he is not mentioned in Pythian 8, was included in the ensemble of Aiakidai transported from Aegina. Still, when Herodotus speaks of 'the other Aiakidai' who are to be brought to Salamis from Aegina, he cannot mention Ajax and Telamon by name, since he has already said that they had been invoked from Salamis. It would be contradictory to say that they had to be invoked also from Aegina.

Evidently Herodotus is sensitive to an Athenian way of thinking here. We know that Ajax and Telamon, as cult heroes of Salamis, could be claimed by the Athenians as their own, since Salamis had become an Athenian possession already in the sixth century. And the wording of Herodotus makes it explicit that the combined forces of the Hellenes had first invoked Ajax and Telamon at Salamis before they sent an Aeginetan ship to bring 'Aiakos and the other

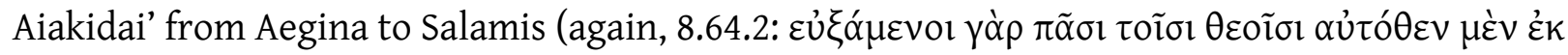

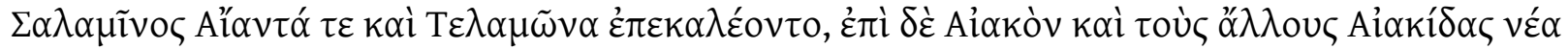

\footnotetext{
${ }^{21}$ Nagy 2003:ix.
} 


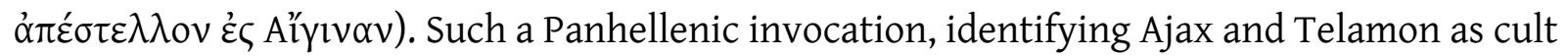
heroes of Salamis, would have differed from an invocation made by Aeginetans, who claimed Ajax and Telamon as their own native sons.

The answer I have just formulated is a reconstruction that is based so far only on a comparison between the wording of an Aeginetan ode by Pindar and the wording of the narrative of Herodotus about [[51|52]] the Aeginetan successes in the naval battle at Salamis. In order to formulate a more decisive answer, I propose to consider the identities of the Aiakidai in the Hesiodic tradition.

The sons of Aiakos, as they are named in the Hesiodic Catalogue, were Peleus, Telamon, and Menoitios (Hesiod F 212a). And, as we learn from the Hesiodic Theogony, there was also a halfbrother named Phokos, the 'Seal' par excellence, whose mother was a Nereid named Psamathe, that is, 'Sand' par excellence (Theogony 1004-1005). ${ }^{22}$ It is most noteworthy that, in the myths about all four of these sons of Aiakos, not a single one of them is ultimately localized in the island of Aegina.

Let us start with Peleus and Telamon. As we see in the narrative of Apollodorus (3.12.6), both of these Aiakidai were exiled from Aegina because they killed their half-brother Phokos. We see a reference to this event in an Aeginetan ode of Pindar, Nemean 5 (lines 14-16). Reading the narrative of Apollodorus, we find these further details about Telamon and Peleus:

1. Telamon moved to the island of Salamis, ruled by a king called Kykhreus, whose parents were Poseidon and another daughter of Asopos, named Salamis; Kykhreus died childless and bequeathed the kingdom of Salamis to Telamon, and that hero Telamon became father of Ajax $(3.12 .6){ }^{23}$

\footnotetext{
${ }^{22}$ West 1985:101.

${ }^{23}$ Other versions are collected by Frazer 1921 II 59n1.
} 
2. Peleus moved to Phthia in Thessaly, ruled by a king called Eurytion, who gave a portion of his kingdom of Phthia to Peleus (3.13.1), and that hero Peleus became father of Achilles (3.13.6).

Telamon and Peleus must be contrasted with Menoitios. The narrative of Apollodorus locates both Menoitios and his son Patroklos in the kingdom of Peleus in Phthia; they had emigrated there because they were exiled from the kingdom of Opous in East Locris, where Patroklos had been guilty of a homicide (3.13.8). In Phthia, they were epoikoi 'immigrants' (again, 3.13.8). The Homeric Iliad shows the earliest attested version of this narrative (XXIII 8490). In the Iliad, however, the father of Menoitios is not Aiakos but one Aktor (XI 785, XVI 14). So Patroklos is not descended from Aiakos in the Iliad. [[52|53]]

This version of the myth is also attested in Pindar's Olympian 9, an ode composed in honor of an athletic victor from Opous in East Locris. This ode shows clearly the native Locrian version of the myth. As we see in Olympian 9, the myth narrates the establishment of the kingdom of Opous after the Great Flood: immigrants came to settle there, and the most honored of these was Menoitios (lines 69-75). ${ }^{24}$ Here in Olympian 9 we see another instance of the word epoikoi 'immigrants' (line 69), which refers to the list of relocated heroes headed by Menoitios. The hero Menoitios is described as the father of Patroklos (line 75); his own father was the hero Aktor (line 69) and his mother was the nymph Aegina (line 70).

This Aegina, however, is figured as a nymph who is not the same as the nymph Aegina from whom Aiakos and the Aiakidai originated. And yet, this other Aegina may be an Asopid nymph in her own right, just as the mother of Aiakos is an Asopid nymph. The difference is, this nymph Aegina is localized in Opous and can be linked with Opountian myths of anthropogony

\footnotetext{
${ }^{24}$ See also the Scholia A for Iliad XVIII 10-11a.
} 
- just as the nymph Aegina who is mother of Aiakos can be linked with corresponding Aeginetan myths.

We now come to Phokos, the fourth and last of the four sons attributed to Aiakos in the Hesiodic tradition. In the Hesiodic Catalogue, the killing of Phokos by his half-brothers Telamon and Peleus leads to the emigration of the two sons of Phokos, the heroes Krisos and Panopeus, to the territory of Phocis (Phokis), where these two sons become the eponymous heroes of the cities Krisa and Panopeus (F 58.7-11). There is more to be said about the localization of Phokos himself: he is linked to Aiakos - but not to the Aiakos of Aegina. As West remarks, "[w]hen Aiakos has intercourse with the Nereid Psamathe and so becomes the father of Phokos, he is still located on the Malian Gulf [in Thessaly]."25

For West and others, the figure of Aiakos belongs first and foremost to the Gulf of Malis in Thessaly, and he is transposed only later to the island of Aegina ${ }^{26}$ West cites as evidence the Homeric Iliad as we have it, where Aiakos seems to be a Thessalian, as are also his son [[53|54]] Peleus and his grandson Achilles (XXI 189). ${ }^{27}$ West observes that the patronymic Aiakidēs 'descendant of Aiakos', which occurs over two dozen times in the Homeric Iliad and Odyssey, always refers to Peleus or Achilles, never to Ajax. ${ }^{28}$ According to this line of reasoning, Aiakos as the father of the Thessalian Peleus was originally a Thessalian in his own right.

By contrast, Telamon was not a Thessalian. I should add that Apollodorus (3.12.6), on the authority of Pherecydes (FGH 3 F 60), reports a myth claiming that Telamon, father of Ajax, was

\footnotetext{
${ }^{25}$ West 1985:163-164.

${ }^{26}$ West 1985:162-163. See also Fowler 1998:12-14.

${ }^{27}$ West 1985:162.

${ }^{28}$ West 1985:162. To be contrasted is the symmetry of Achilles and Ajax in the pedimental sculptures of the temple of Aphaia in Aegina, on which see Fearn 2007:96-100.
} 
not even a brother but merely a friend of Peleus, and that the father of Telamon was Aktaios while his mother was Glauke, daughter of Kykhreus of Salamis. ${ }^{29}$

By now we can see why I said earlier that not a single one of the Aiakidai is ultimately localized in Aegina. But the question remains: what about Aiakos himself?

West thinks that the genealogy of Aiakos - Peleus - Achilles comes "from a south Thessalian or Malian (Myrmidon) Märchen-type tradition which was drawn into and absorbed in the Trojan saga at a fairly late stage of the latter's development." ${ }^{30}$ In this formulation, he mentions the Myrmidons of Thessaly because he also thinks that Aiakos is "the local Urmensch"

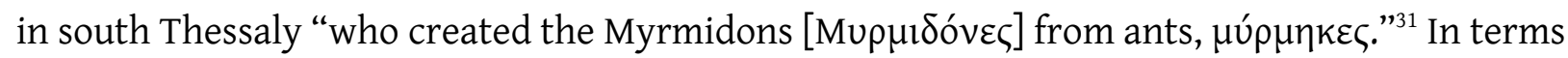
of West's thinking, a myth about the creation of Myrmidons (Murmidones) from ants (murmèkes) was relocated from Thessaly to Aegina, and the myth about the creation of the Aeginetans from ants in the Hesiodic Catalogue (F 205) results from such a relocation. ${ }^{32}[[54 \mid 55]]$

In what follows, I offer a different formulation. In terms of this formulation, as we will see when we take a closer look at the Thessalian and the Aeginetan traditions, Aiakos can be considered a native to both Thessaly and Aegina.

\footnotetext{
${ }^{29}$ Frazer 1921 II 53-54n7.

${ }^{30}$ West 1985:162.

${ }^{31}$ West 1985:162-163.

${ }^{32}$ West 1985:163n84. This theory about a relocation of the Aiakos myth from Thessaly to Aegina helps shape various other arguments concerning the contacts of Aegina with the Amphiktyones controlling Delphi: see the impartial analysis of Fearn 2007:102n60, especially with reference to the arguments of Fowler 1998 and Rutherford 2005. On the close cultural links between Aegina and Delphi, especially as reflected in Pindar's Paean 6, I am guided by the work of Kowalzig 2007 ch. 4; of particular interest to me are pp. 186-188, 194; also pp. 195-201 (a section entitled "The Sacred War Traditions"). At pp. 197-198 there is a most useful analysis of the important work of Hall 2002 on "Hellenic" identity.
} 


\section{Myrmidons}

I start with the Thessalian traditions, focusing on the concept of Myrmidons. A prominent example is Patroklos, son of Menoitios: this hero Patroklos is described as 'the best of the

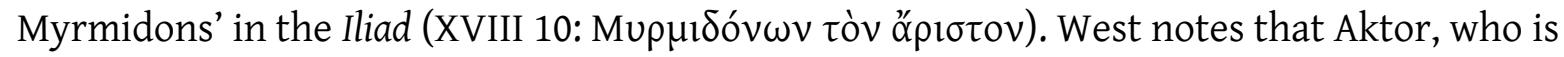
named in the Iliad as the father of Menoitios and the grandfather of Patroklos (XI 785, XVI 14), is comparable to the Aktor named in the Hesiodic Catalogue as originating from a mother named Peisidike and from a father named Myrmidon, who is a son of Zeus (F 10a.99-101; Apollodorus 1.7.3)..$^{33}$ In terms of this genealogy, the name Myrmidon cannot be localized in Aegina. I quote a formulation by West concerning the relevant testimony of the Hesiodic Catalogue (F 10a.99-101 and F 212a): "the sequence Aegina - Menoitios - Patroklos was detached from Aktor (leaving Myrmidon's family a mere stump ...) and conflated with the sequence Aegina - Aiakos - Peleus - Achilles, Menoitios becoming Peleus' brother." ${ }^{\prime 34}$ As West notes, this Myrmidon who is son of Zeus is the eponymous ancestor of the Myrmidons of Thessaly. ${ }^{35}$

Next I turn to the Aeginetan traditions, again focusing on the concept of Myrmidons. This concept is central to the myth telling how Zeus, in order to create human company for his lonely son Aiakos, changed into humans the ants native to the Mother Earth that is Aegina (Hesiod F 205, Apollodorus 3.12.6). We know from sources such as Strabo (8.6.16 C375) that the autochthonous people of Aegina were actually known as Myrmidons (Murmidones). ${ }^{36}[[55 \mid 56]]$

\footnotetext{
${ }^{33}$ West 1985:163n85.

${ }^{34}$ West 1985:163.

${ }^{35}$ West 1985:61.

${ }^{36}$ See also the Scholia D for Iliad I 180. In the account of Strabo (8.6.16 C375) concerning the naming of the Aeginetans as Myrmidons, he does not refer to the aetiological myth about Aiakos and his ants, preferring instead an alternative explanation involving the excavating habits of ants as a model for traditional practices of the Aeginetans in excavating their land. In any case, Strabo accepts as facts (1) the naming of the Aeginetans as Myrmidons and (2) the association of the Myrmidons with murmēkes 'ants'. See also the scholia for Pindar Nemean $3(21)$.
} 
West sums up the myth this way: "Zeus created a people for him [= Aiakos], the Myrmidons

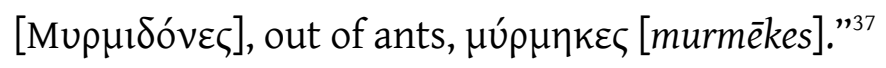

As we saw earlier, West thinks that the Myrmidons originate from Thessaly, and that Aiakos therefore must also originate from there. I submit, however, that there is no reason to presuppose a single myth about humans called Myrmidons who are created from ants.

The linking of the name Murmidōn with murmèx, the word for 'ant', is attested elsewhere as well: for example, there is a myth that tells how Zeus transformed himself into a murmēx 'ant' in order to impregnate a nymph named Eurymedousa, who gave birth to Murmidōn (Clement of Alexandria Protrepticus 2.39.7).

And we know also of other anthropogonic myths about the creation of humans from ants: for example, there is a myth that tells of a heroine named Melite, eponym of an Attic deme ( $\delta \tilde{\eta} \mu \circ \varsigma)$, who was the daughter of Murmèx, the Ant par excellence (Hesiodic Catalogue F 225). ${ }^{38}$

There are also typological parallels. ${ }^{39}$ Anthropogonic myths about autochthonous populations generated from colonies of ants or termites are attested in a variety of cultures that have no historic or prehistoric connections with the ancient Greeks, especially in Africa. ${ }^{40}$

Aside from the sources I have cited so far concerning a link between the autochthonous Aeginetans and the Myrmidons, we have further evidence in the wording of Pindar himself. In one of his Aeginetan odes, Nemean 3 (line 13), the 'earlier' (proteroi) people of Aegina are explicitly said to have been the Myrmidons (Murmidones). ${ }^{41}$

The ostentatious application of the adjective proteroi 'earlier' to the Myrmidons of Aegina in Pindar's Nemean 3 implies a complication. [[56|57]] The Aeginetans who inhabit the island of

\footnotetext{
${ }^{37}$ West 1985:101.

${ }^{38}$ See West 1985:108, 170 .

${ }^{39}$ On the concept of a typological parallel, see Nagy $2005 \mathrm{~b} \$ 4$.

${ }^{40}$ For African examples, see Baumann 1936:27, 46, 87-88, 144, 179, 181, 215, 216-219, 224, 283, 371.

${ }^{41}$ For other sources that localize the Myrmidons as originating from Aegina, see West 1985:163n84.
} 
Aegina in the present time of this Aeginetan ode are not only Myrmidons by origin. The complication has to do with the fact that the population of Aegina was basically Dorian. In terms of local Aeginetan mythology, the prototypical Aeginetans must have intermarried with immigrant Dorians: in Pindar's odes, these notional immigrants are figured as the official founders of Aegina as a polis or city-state (Isthmian 9.1-4, Olympian 8.30). ${ }^{42}$ Also, again in terms of local Aeginetan mythology, at least some if not all of the autochthonous Myrmidons of Aegina must have abandoned their island and followed Peleus to Phthia when Peleus was exiled for killing his half brother Phokos (Strabo 9.5.9 C433).

It is in the context of this ostentatious reference to the 'earlier' people of Aegina that the Pindaric scholia for Nemean 3 (at line 21 in the older colon-based line-numbering system) quote the verses of the Hesiodic Catalogue (F 205) concerning the Myrmidons as the autochthonous people of Aegina who ultimately turned to seafaring as a way of life.

In the logic of this myth as retold in Hesiodic poetry, the autochthonous population of Aegina, originating from the ants generated by the local earth, invented the maritime technology of shipbuilding and navigation. This aetiology suits Aeginetan society: as we have seen, the Aeginetans were conventionally celebrated as a seafaring people.

\section{Aeginetans as autochthons and migrants}

There is a paradox inherent in this aetiology. These autochthonous and therefore inherently non-migratory Aeginetans, indigenous as they are to their own Mother Earth, become the most migratory of humans, traveling all over the seas despite their non-migratory origins.

\footnotetext{
${ }^{42}$ For more on the Dorian component of Aeginetan identity, see Kowalzig 2007:203-207, who connects this component with the myths concerning the Sacred War.
} 
In this same Aeginetan ode of Pindar, Nemean 3, the deeds of the sons of Aiakos are narrated (starting at line 28) with an emphasis on [[57|58]] their origins in Aegina, native land

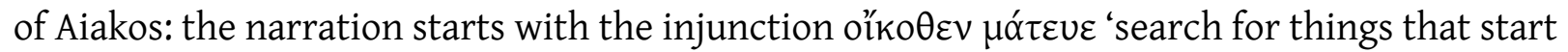
at home' (line 31). The first in a series of three subjects in this compressed narration is Peleus (named at line 33) and the second is Telamon (named at line 36), and then the third and most highlighted subject is Achilles (named at line 43), whose deeds are narrated with special pride (all the way to line 64). Then, as the narration reaches its conclusion, the glory of all three heroes is pointedly traced back to the beacon light of the Aiakidai, which shines forth from

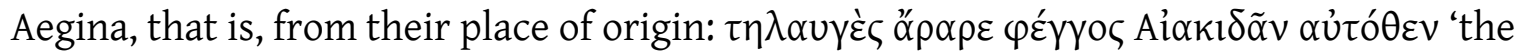
beacon light of the Aiakidai, shining far and wide, is grounded as starting from right here' (line 64). The wording $\alpha$ ủ $\tau o ́ \theta \varepsilon v$ 'starting from right here' rounds out the narration by bringing it

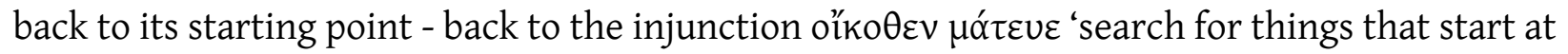
home' (line 31).

This wording aủ $\tau$ ó $\theta \varepsilon v$ 'starting from right here' in Pindar’s Nemean 3 (line 64) is comparable to the same wording $\alpha \dot{v} \tau o ́ \theta \varepsilon v$ as used in the narrative of Herodotus (8.64.2) concerning the invocation of the Aiakidai from Salamis, the heroes Ajax and Telamon, at the naval battle of Salamis. In the words of Herodotus, this invocation of these two Aiakidai took place before the conveying of 'Aiakos and the other Aiakidai' from Aegina to the naval battle of

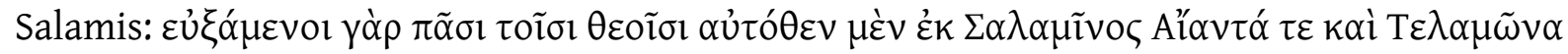

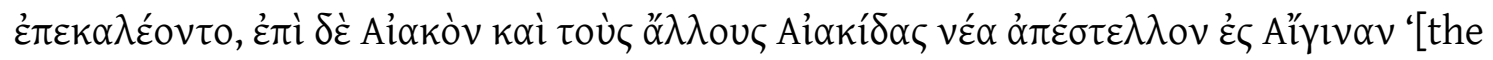
Hellenes] prayed to all the gods, and then they invoked [epi-kaleisthai] Ajax and Telamon to come from right there [autothen], from Salamis, but they sent for Aiakos and the other Aiakidai to come [from Aegina], sending on a (naval) mission [apo-stellein] a ship to Aegina' (8.64.2). 
I come back to the wording aủtó $\theta \varepsilon v$ (autothen) ‘starting from right here' in Pindar's Nemean 3 (line 64), which rounds out the narration by bringing it back to its starting point - back to the

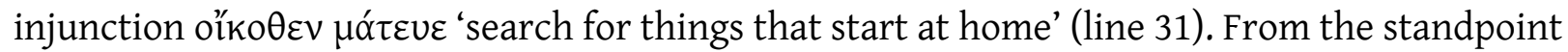
of local Aeginetan mythology, that is how it all started, with Aiakos as the native son of Aegina.

To be contrasted is the formulation of West, which I have already quoted. Here I repeat only the essence, which is, that the genealogy of Aiakos - Peleus - Achilles originated "from a south Thessalian or [[58|59]] Malian (Myrmidon) Märchen-type tradition." ${ }^{\prime 3}$ That may be so, as far as the sequence of Aiakos - Peleus - Achilles is concerned. But it does not follow that this genealogical sequence was simply relocated from Thessaly to Aegina. Such a relocation, as argued by West, would mean that Aiakos himself originated from a Thessalian tradition. But that does not necessarily follow. Aiakos may have originated from an Aeginetan tradition as well.

In making his argument that the genealogy of Aiakos was transposed from Thessaly to Aegina, West notes that there may have been convergent names common to both places that made such a relocation possible. For example, he notes the existence of a Thessalian river named Asopos that flowed into the Gulf of Malis (the river is mentioned by Herodotus 7.199200). ${ }^{44}$ By implication, Aiakos could have been the son of an Asopid nymph who was impregnated by Zeus in Thessaly: "[s]o Aiakos' mother may have been an Asopid from the beginning, and there is no reason why her name should not have been Aegina, for it is a name that occurs in several places (Epidaurus, Ios, Paphlagonia), and there might have been an Aegina in Malis," that is, in the region of the Malian Gulf in Thessaly. ${ }^{45}$

\footnotetext{
${ }^{43}$ West 1985:162.

${ }^{44}$ West 1985:163.

${ }^{45}$ West 1985:163.
} 


\section{Contractual mythology}

But there is more to it. It is not that the Aeginetans made the gesture of relocating from Thessaly a native Thessalian myth about Aiakos and a mother named Aegina by linking this myth with their own native Aeginetan myth about their own nymph named Aegina. From the standpoint of the Hesiodic Catalogue, the pathway for the relocation of myths must have been a two-way street, as it were, not one-way from Thessaly to Aegina. In the case of a Thessalian son of Aiakos like Peleus, for example, his father Aiakos must be an Aeginetan just as surely as Peleus must be a Thessalian. In other words, the Peleus of the Thessalians must have an Aeginetan father named [[59|60]] Aiakos, not a Thessalian father named Aiakos. From the standpoint of the Catalogue, the Aeginetan Aiakos must be accepted by Thessaly just as surely as the Thessalian Peleus must be accepted by Aegina. For the Thessalians as also for the Aeginetans in this case, there can be only one hero named Aiakos and only one hero named Peleus. The mythological perspective of the Catalogue is "contractual," organically unifying two cognate but independent genealogies into a codependency.

For the "contract" to work, there can be only one autochthonous Aiakos, and he is the one in Aegina. And there can be only one Peleus. For the "contract" to work, this Peleus will have to emigrate from Aegina and then immigrate to Thessaly. As the son of Aiakos, Peleus cannot be an autochthonous native son of Thessaly, since Aegina must retain Aiakos as the island's very own autochthon. Such a "contractual" relationship between Thessalian and Aeginetan myths is what we see formalized in the Hesiodic poetry of the Catalogue.

A question remains. From the standpoint of the Hesiodic Catalogue, what is the location of

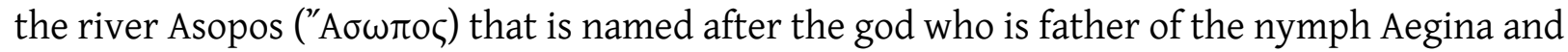
grandfather of Aiakos in that hero's role as native son of the island of Aegina? Since Aiakos must be the autochthonous hero of the land that is Aegina, it follows that the river that is 
Asopos must be linked to this same land, not to Thessaly. But how can this link be reconciled with the existence of a river named Asopos in Thessaly, as noted by West? ${ }^{46}$ The answer is simple: there can be no such reconciliation, and so the river Asopos in Thessaly has to be excluded from the contractual relationship between the Thessalian and Aeginetan myths. That is because Aiakos as the autochthonous son of an Asopid in Aegina cannot be at the same time the autochthonous son of an Asopid in Thessaly. In terms of any single myth as mediated by the Hesiodic Catalogue, there can be only one Asopid nymph who is mother of Aiakos. And there can be only one place where the Asopid nymph gives birth to Aiakos, and that is the land of Aegina named after the nymph that is Aegina. [[60-61]]

\section{Multiple daughters of Asopos}

Although the land of Aegina claims to be the one and the only place where the nymph Aegina, as daughter of the river Asopos, gave birth to the native hero of the land, there can be more than one place for other daughters of the river Asopos to give birth to other native heroes of other lands. Here I come to the essence of the title of this presentation, "Asopos and his multiple daughters." The fact is, there is more than one nymph who is daughter of the river Asopos. There is a multiplicity of Asopid nymphs. And part of the reason for this multiplicity is a corresponding multiplicity of streams named Asopos. We have already noted two instances. As we have seen, there is a river named Asopos in Thessaly, and there is another one in Boeotia, near the city of Thebes.

Whereas the Thessalian river Asopos is excluded from the Aeginetan myth of Aegina the Asopid nymph, the Boeotian river Asopos is included. Let us review briefly the role of the Boeotian river in the Aeginetan myth. According to this myth as retold in Pindar's Isthmian 8

\footnotetext{
${ }^{46}$ As we have already seen, West 1985:163 draws attention to the existence of this Thessalian river Asopos.
} 
(lines 16-31), the nymph Aegina is the twin sister of a nymph named Thebe ( $\Theta \dot{n} \beta \eta$ / $\Theta \dot{\eta} \beta \alpha)$, local goddess of Thebes $\left(\Theta \tilde{\eta} \beta \alpha_{l}\right)$, and these nymphs are daughters of Asopos, who is the god of the river Asopos that waters the land of Thebes. The myth tells how Zeus abducted the Asopid nymph Aegina from this land and relocated her in the land of Aegina, where she was impregnated by the god and gave birth to Aiakos. As we have seen, the detail about the impregnation of the Asopid nymph Aegina by Zeus in the land of Aegina is already attested in the Hesiodic Catalogue (F 205).

From the fragments of the Hesiodic Catalogue that are known to us so far, we do not know for certain whether the Boeotian identity of the river Asopos was actually specified in the retelling of the myth about the abduction of the Asopid nymph Aegina by Zeus and about her relocation in the land of Aegina. It is important to take note of this uncertainty because there exists an alternative myth about the abduction of this Asopid. This alternative myth involves yet another river named Asopos - other than the Thessalian and the Boeotian rivers of the same name. This third river named Asopos is located in [[61-62]] the north-east Peloponnesus, flowing through the territory of the state of Phleious and emptying into the Gulf of Corinth in the territory of the state of Sikyon. In what follows, I will concentrate on the myth about the river Asopos as mediated by the state of Phleious. (I should note that Phleious was also known as Phlias, whence the conventional adjective 'Phliasian'.)

According to a Phliasian myth that was linked with the Peloponnesian river Asopos, Zeus relocated the Asopid nymph Aegina to the land of Aegina after having abducted her from Phleious, not from Thebes; this alternative myth is attested by Diodorus (4.72). ${ }^{47}$ In the Phliasian myth, Aegina was abducted from the banks of the Phliasian Asopos, not the Theban Asopos.

\footnotetext{
${ }^{47}$ Fearn 2003:359.
} 
As we learn from Pausanias, this Phliasian myth about the abduction of the nymph Aegina from Phleious was unacceptable to the Thebans, who claimed that the Asopid nymph Thebe was the daughter of the Boeotian rather than the Peloponnesian Asopos (2.5.3). ${ }^{48}$

So when Zeus abducted Aegina from the banks of the river Asopos, which river was originally meant? From the viewpoint of mythmaking, choices need to be made about locating the original Asopos. This river must have originated either in Boeotia or in the Peloponnesus or even in Thessaly, for that matter. From the viewpoint of empirical observation, however, there is no single original river of choice. An application of the comparative method shows that the mutually contradictory myths about Asopos are cognate with each other and need to be analyzed as multiform variants. ${ }^{49}$ The multiplicity of streams named Asopos cannot be explained in terms of any single original myth about such a stream. We have already seen a comparable phenomenon in the multiplicity of notionally autochthonous populations named after ants. In this instance as well, we cannot explain such multiplicity in terms of any single anthropogonic myth about ants turning into humans. [[62-63]]

\section{The meaning of the name of Asopos}

The mention of anthropogony in this context is actually relevant to the myths about the river god Asopos, since the name of this god is connected to the theme of human creation. The connection becomes evident from a detail embedded in the retelling of Apollodorus (3.12.6). It is said that when Zeus abducted the nymph Aegina from the banks of the river Asopos, the river god became so angry that his waters overflowed abnormally as he pursued Zeus, who reacted by striking the waters with his flaming thunderbolt, thus restoring the normal flow of

\footnotetext{
${ }^{48}$ Fearn 2003:359-360.

${ }^{49}$ For further observations about the uses of comparative methodology in the study of cognate mythological variants, see Nagy $2005 b \S 5$.
} 
the river. And because the fiery thunderbolt of Zeus made this violent contact with the waters of the river, it is said that even now you can see anthrakes 'glowing coals' rising up from the depths of these waters. I quote the relevant wording in the retelling of Apollodorus (again,

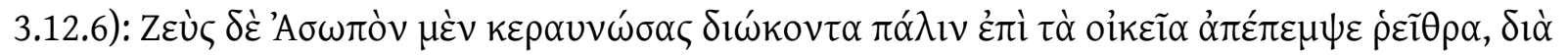

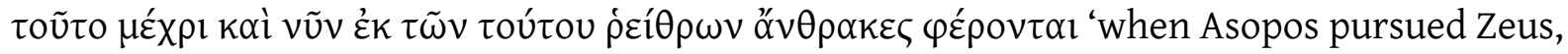
Zeus struck him with his thunderbolt and thus restored the river to its familiar course, and that is why even to this day there are glowing coals [anthrakes] produced by the streams of this river'. As we are about to see, the connection of the word anthrakes 'glowing coals' with the name Asoppos in this myth is parallel to the connection of the same word anthrakes 'glowing coals' with the word for 'human beings', anthrōpoi.

The connection of anthrakes 'glowing coals' with anthrōpoi 'human beings' is attested in what appears to be an anthropogonic myth about the notionally autochthonous population of the Athenian deme of Akharnai. This myth is prominently ridiculed in the comedy by Aristophanes named the Acharnians. In terms of such a local Acharnian myth, this human population was created from anthrakes 'glowing coals' contained in a sacrificial brazier. ${ }^{50}$

In terms of such a localized anthropogonic myth, the noun anthrōpos 'human being' can be understood as a compound formation meaning basically 'having the looks of glowing coals'. There are a [[63-64]] number of semantic parallels in Indo-Iranian myths about the creation of humans from the glowing coals of sacrificial fire..$^{51}$

\footnotetext{
${ }^{50}$ In Nagy 1990b:151-152n30, I offer an analysis of relevant passages in Aristophanes Acharnians.

${ }^{51}$ Again, Nagy 1990b:151-152n30.
} 
Similarly, the noun Asōpos can be understood as a parallel compound formation meaning basically 'having the looks of glowing coals'; in this case, the root as- in Asōpos is cognate with the root as- in the noun asbolos / asbole, which refers to the sparks emitted by glowing coals. ${ }^{52}$

Such an etymology of the noun Asōpos indicates that the name of the river god is connected to myths of anthropogony. And this connection is validated by the local Aeginetan anthropogonic myth about the god Asopos as the father of the nymph Aegina, who in turn is the Mother Earth that generates the first human being in the land of Aegina. And it is further validated by another local Aeginetan anthropogonic myth - this one about the supplementary human beings who are created from the ants that populate the land of Aegina.

\section{Multiple versions of Asopos}

But the question remains, did the Hesiodic Catalogue feature a Phliasian or a Theban version of the river god Asopos? In the narrative of the Catalogue, did Zeus abduct the daughter of the river Asopos in Phleious or the daughter of the river known by the same name in Thebes? In what follows, I argue that the river of choice was in fact the Asopos of Thebes.

I start with a detail mentioned by Pausanias, who notes that even the Phliasians acknowledged that the river Asopos had a daughter named Thebe (2.5.2). This detail is most significant, since it connects the myth about the abduction of Aegina with the Boeotian state of Thebes - and thus with the Boeotian river of Asopos.

Such an acknowledgment on the part of the Phliasians is also evident in an ode of Bacchylides (9) celebrating the victory of an athlete who competed at the festival of the Nemea. Significantly, the victorious athlete in this ode was a native son of the city state of [[6465]] Phleious, and the wording of Bacchylides ostentatiously draws attention to the traditions

\footnotetext{
${ }^{52}$ Nagy 1990b:152.
} 
of this city, highlighting the glories of the Phliasian river Asopos (lines $39-61) \cdot{ }^{53}$ It is in this context that the ode celebrates the glories of the multiple daughters of Asopos (starting at line 49).

In the myth of the Asopid nymphs as narrated in this ode of Bacchylides (9), it is made explicit that these nymphs were all relocated 'by the gods' (that is, by Zeus or Poseidon as alternative abductors) and that these same nymphs thus became the originators of great cities (lines 50-52). The first two such cities to be named are Thebes (line 54) and Aegina (line 55).

So even in the Phliasian myth as retold by Bacchylides (9), the nymph Thebe is acknowledged as ultimately belonging to the city-state of Thebes, just as the nymph Aegina ultimately belongs to the city-state of Aegina. From the perspective of the Phliasian myth, only the river Asopos belongs to the state of Phleious, whereas the Asopids Thebe and Aegina no longer belong to it: rather, these nymphs are relocated to the respective states of Thebes and Aegina.

\section{Alternative daughters of Asopos}

Given that the state of Phleious had notionally lost the nymph Thebe to the state of Thebes, just as it had lost the nymph Aegina to the state of Aegina, we may ask whether there was any local nymph that the Phliasians could still claim as their very own Asopid. An answer emerges from a comparison of two passages taken from Pausanias.

In the first of these passages, Pausanias briefly retells what he describes as a Phliasian myth concerning Asopos and three of his daughters, two of whom are Aegina and Thebe while the third is Corcyra (2.5.2); as Pausanias adds, the city state of the island of Corcyra was named after the nymph Corcyra, just as the city states of Aegina and Thebes were named after the

\footnotetext{
${ }^{53}$ In the Phliasian myth as retold by Bacchylides, the river Asopos is at the center of the whole world (9.40-44; see D’Alessio 2005b:238); it is also the king of all rivers (9.45).
} 
nymphs Aegina and [[65-66]] Thebe (2.5.2). The island state of Corcyra was the most prominent of the daughter cities of the mother city or metropolis that was Corinth. I will have more to say later about the relationship between Corcyra and Corinth.

In the second passage, Pausanias mentions a statue group dedicated by the Phliasians at Olympia, featuring Asopos and his daughters. First among the Asopids to be listed is the nymph Nemea; second is Aegina, paired with Zeus, who is seen in the act of abducting the nymph; next to be listed are Harpina, Corcyra, Thebe, and then Asopos himself (5.22.6). ${ }^{54}$ In this same passage, Pausanias attributes to Pindar (F 290) a myth that tells how Thebe was impregnated by Zeus; then he cites an unattributed myth that tells how Corcyra was impregnated by Poseidon. We know from other sources that the son of Corcyra and Poseidon is Phaiax, eponymous ancestor of the Phaeacians (Hellanicus FGH 4 F 77). In this report of Pausanias, it is evident that the Asopid nymphs Aegina, Thebe, and Corcyra represent respectively the states of Aegina, Thebes, and Corcyra. Also, Pausanias here makes it explicit that the myth of the Asopid Harpina, who is impregnated by Ares and who becomes mother of Oinomaos, is shared by the states of Phleious and Elis (again, 5.22.6). As for the figure who takes pride of place in this ensemble, it is the Asopid nymph Nemea, eponym of the site of the Nemean festival. By implication, this Asopid represents the state of Phleious.

In terms of this Phliasian myth, then, the name of the nymph Thebe is accepted as the eponym of the Boeotian city of Thebes. On the other hand, as Pausanias says explicitly, the Thebans reject the Phliasian myth, since for them the river Asopos waters the territory of the Boeotian city of Thebes, not the territory of the Peloponnesian cities of Phleious and Sikyon (2.5.2). This rejection is in part reciprocated by the Phliasians, who evidently deny that the

\footnotetext{
${ }^{54}$ Larson 2001:303n44, who notes also that the Phliasians also dedicated a statue group at Delphi, featuring Zeus and Aegina (Pausanias 10.13.6). See also Fearn 2003:361.
} 
Asopid nymph Aegina was a native of Thebes: rather, she was a native of Phleious, and she was abducted from Phliasian territory when Zeus took her from Asopos and relocated her in Aegina (2.5.2-3). [[66-67]]

\section{Variations on the theme of a virtual Asopos}

Is there any way, then, for the logic of myth to resolve such contradictions? A resolution is in fact evident in the reportage of Pausanias, who goes on to say that the Phliasians and the neighboring Sicyonians do not really claim that the waters of their river Asopos originate from their territory: instead, they claim that these waters are a continuation of the waters of the river Maeander in Asia Minor (2.5.3). ${ }^{55}$ These waters of the Maeander, as Pausanias reports, originate in the mountainous territory of Kelainai, flowing down from there through the territories of Phrygia and Caria and emptying into the sea near the city of Miletus, from where these same waters continue to flow under the world - until they surface again in the Peloponnesus, forming the river Asopos (again, 2.5.3). ${ }^{56}$ From here on, I will refer to this underworldly stream as a virtual Asopos.

By implication, the waters of such a stream that flows under the known world could surface not only in the territory of Phleious but elsewhere as well, as in the territory of Thebes. That is why, from the standpoint of the Phliasians, the streams of this virtual Asopos can water the territory of Thebes as well as the territories of Phleious and Sikyon. And that is why this stream can father the nymph Thebe as well as the nymph Aegina.

I turn to a second instance of such a virtual Asopos. Again it involves the river Maeander. The underworldly passage of this river is indicated also in another myth besides the myth

\footnotetext{
${ }^{55}$ Fearn 2003:366.

${ }^{56}$ In the Peloponnesus, the waters of the Asopos emanate from the mountainous heights overlooking the territory of Phleious. In one of Pindar's Aeginetan odes, Nemean 6 (line 44), there is a reference to these mountainous heights. In Pindar's Nemean 9 (line 9), we see a reference to the streams of this Peloponnesian Asopos.
} 
deriving from the state of Phleious. This other myth derives from the island state of Samos. According to local Samian traditions as reflected in the poetry of a Samian native named Asios (F 7 ed. Bernabé; via Pausanias 7.4.1), the island of Samos was named after a nymph called Samia who was daughter of the river Maeander. ${ }^{57}$ As we have seen in the [[67-68]] myth deriving from the state of Phleious, this river Maeander is notionally identical with the river Asopos in the making. As we have also seen, the waters of the Maeander emptied into the sea near the city of Miletus - that is, in the territory of Priene facing the island Samos. In terms of the Samian myth, then, I infer that the waters of the virtual Asopos come to the surface in the land directly facing the land where the Maeander empties into the sea, that is, in the land of the island that is Samos. ${ }^{58}$

We are about to see references to such a local Samian myth in two songs, one by Ibycus and the other by Anacreon. These references are especially significant because both Ibycus and Anacreon evidently composed these two songs under the patronage of Polycrates, who was tyrant of Samos and who presided over a powerful thalassocracy centered in Samos. ${ }^{59}$

In the case of the song composed by Ibycus (F 322), we know from Strabo (6.2.4 C271) that it

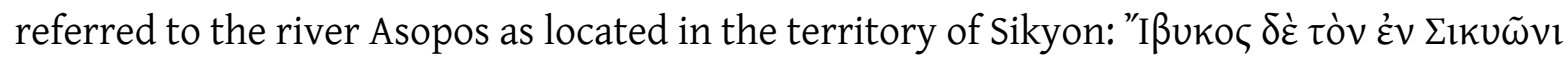

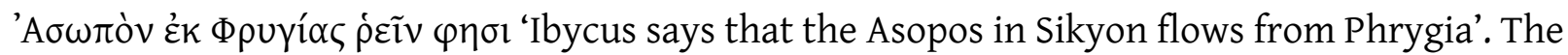
mention of Sikyon is most relevant, since we know that Ibycus actually composed songs that were directly relevant to the politics of Sikyon (F 282 / S 151). ${ }^{60}$

\footnotetext{
${ }^{57}$ Larson 2001:123 analyzes this Samian myth.

${ }^{58}$ We see a comparable mythological construct originating from the environs of Miletus: a spring on the mountain called Mykale was imagined to flow down underground from the heights and then to flow further under the Carian Sea until it surfaced as a spring at the sacred site of Didyma. The sources, including Pausanias 5.7.5, are analyzed by Herda 2006:81-82 with note 215 .

${ }^{59}$ Both Herodotus (3.39.3-4) and Thucydides (1.13.6) comment on this thalassocracy.

${ }^{60}$ There is a relevant discussion by Barron 1964:223-226. Though I do not agree with many of the inferences in this discussion, I do agree that the poetry of Ibycus (as reflected in the genealogies of Ibycus F 282 / S 151) is not
} 
In the case of the song composed by Anacreon (F 448), we know from Hesychius (A 7926 s.v.) that this song described Samos as 'the city of Nymphs': $\alpha$ $\sigma \tau v ~ N u \mu \varphi \varepsilon ́ \omega v \cdot \tau o ̀ v ~ \sum \alpha ́ \mu o v$

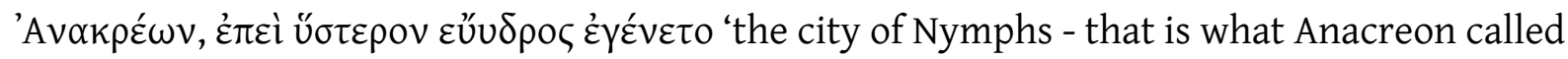
[[68-69]] Samos, since it became well-watered at a later time'. At a later point, I will offer an explanation for the reference here to 'a later time'. For now, however, I simply add a further piece of relevant lore: as we know from Athenaeus (15.672b), it was said that the temenos 'precinct' of Hera in Samos was founded in primordial times by the Leleges and the Nymphs.

I add a third instance of a virtual Asopos. The nymph Sinope is said to be the daughter of Asopos (Eumelus of Corinth F 10 ed. Bernabé; also Aristotle F 540 ed. Rose; via scholia for Apollonius of Rhodes Argonautica 2.946). Named after this nymph is the city of Sinope, a colony of Miletus situated on a promontory along the south coast of the Black Sea. In the context of Milesian traditions, Asopos is to be identified with the river in Boeotia. ${ }^{61}$

By now we have seen three variations on the theme of a virtual Asopos. In the first instance, the virtual Asopos comes to the surface at Phleious; in the second, at Samos; and, in the third, at Sinope. In each of these three instances, Asopos is imagined as an underworldly stream of fresh water that pushes upward from below the earth and then surfaces as a spring in a mountainous region. The stream from that spring then flows downward from the heights and become a great river by the time it empties into the sea. In the case of the river Maeander, we see that it can even restart as a spring after becoming a river, since the stream of this river is imagined as going underground near Miletus and then resurfacing somewhere else as a spring in some another mountainous region.

compatible with the politics of Sikyon during the era of the tyrant Cleisthenes - or with the politics of Athens in general. On the other hand, the poetry of Ibycus is compatible with the politics of Sparta, and the same can be said about the poetry of Stesichorus: see West 1985:133, 135.

${ }^{61}$ Herda 2006:78n198. 


\section{Another kind of daughter for a virtual Asopos}

There was also an alternative way of imagining a virtual Asopos. The stream of the spring can stay underground as it flows downward from the mountainous heights - until it surfaces at a spring located in the center of the city. Such a spring would be another kind of daughter for Asopos. [[69-70]]

A prime example is a spring named after the nymph Peirēnē, located in the city center of Corinth ${ }^{62}$ It is described in some detail by Pausanias (2.2.2-3), who goes on to mention a myth that identifies Peirēnē as the daughter of the river Akhelōios (2.2.3). From the immediate context of this identification, I infer that the source used by Pausanias here is a piece of poetry. I have two reasons for making this inference. First, Pausanias goes on to mention an alternative myth that identifies Peirēnē as the daughter of one Oibalos, and the source of this myth is definitely poetic: it is the Catalogue of Hesiod (F 258). Second, as we see from another context, Pausanias views the river Akhelōios as a mythical construct: it is viewed as a primal stream that generates all other streams (8.38.10). And the source used by Pausanias for such a myth about the river Akhelōios as a primal stream is likewise definitely poetic: it is the Homeric Iliad (XXI 194). ${ }^{63}$

Something is amiss, however, when Pausanias identifies the nymph Peirēnē as the daughter of the river god Akhelōios (2.2.3). If I am right that his thinking here about Peirēnē is based on his readings in poetry, what has happened is that he has momentarily lost track of the Corinthian version of the myth about the spring he is describing. It does not take long for

\footnotetext{
${ }^{62}$ I am grateful to Betsey Robinson for showing me relevant portions of a forthcoming work of hers, Histories of Peirene: A Corinthian Fountain in Three Millennia.

${ }^{63}$ As we see from the reportage of Pausanias (8.38.10), it is evident that he is following a version of the text of Iliad XXI 194-197 that does not include the verse we know as XXI 195, where the Okeanos is privileged over the Akhelōios as the primal stream. For more on the Akhelōios, see D'Alessio 2004.
} 
him to get back on track, however, as he proceeds to report the local Corinthian myth about the nymph Peirēnē. According to the Corinthian version, as we are about to see from the further reportage of Pausanias, the father of this nymph who presides over the spring located in the city center of Corinth is not Akhelōios but Asopos.

Pausanias reports that the spring of Peirēnē in the city center of Corinth was said to be connected to another spring located on the summit of the Acrocorinth, near the temple of Aphrodite (2.5.1-2). Pausanias speaks of this spring on the Acrocorinth as a gift of the river god Asopos to the hero Sisyphus, a primeval king of Corinth. When Zeus abducted Aegina the daughter of Asopos, the trickster Sisyphus found out about the deed but withheld information from [[70-71]] Asopos until the river god gave him the gift of water. This gift, in the myth as retold by Pausanias (2.5.1), is the spring on the Acrocorinth.

According to the local Corinthian lore, as Pausanias reports, the waters from this spring flow underground all the way down from the heights of the Acrocorinth and join with the

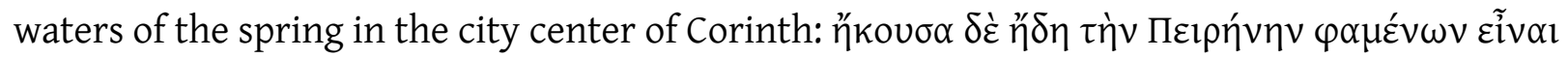

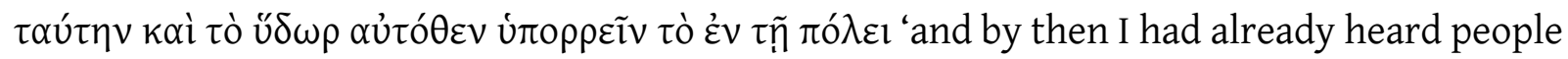
say that this spring [on the Acrocorinth] was Peirēnē, and that the waters that flow

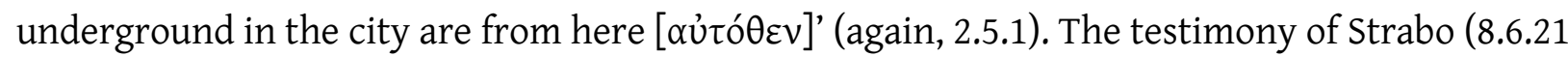
C379) confirms this tradition. In terms of this local Corinthian tradition, then, the waters of the spring in the city center are the same as the waters of the spring on high at the Acrocorinth. ${ }^{64}$

\footnotetext{
${ }^{64}$ As Robinson shows in the work I have cited in the previous note, the idea that the waters of the spring on the Acrocorinth and of the spring in the city center are one and the same cannot be sustained on the basis of what we know from the modern science of hydrology. Still, as she points, out, it is understandable that even a scientific thinker like Strabo would be swayed by the thinking reflected in the hydrological myths about the "upper" and "lower" springs of Peirene.
} 
We can now connect this tradition with an essential fact. As we know explicitly from another source, the name of the nymph of these waters, Peirēnē, is also the name of yet another daughter of Asopos (Diodorus 4.72).

It is evident that Pausanias recognizes the nymph Peirēnē of Corinth as an Asopid. After tracing the waters that flow down underground from the spring on the summit of Acrocorinth to the spring of Peirēnē in the city center of Corinth (2.5.1), he immediately proceeds to tell about the river Asopos itself, which he identifies with the Asopos that originates from the highlands of Phleious: that river Asopos flows through the Phliasian territory and through the territory of Sikyon before it empties into the Gulf of Corinth (2.5.2). Pausanias then proceeds to retell what he describes as the Phliasian version of the myth about the Asopids, naming the nymphs Corcyra, Aegina, and Thebe in that order (2.5.2). Then and only then does he refer to the rival Theban version of the myth about the Asopids, recording the rival Theban claim that the god who fathered the nymph Thebe was the Boeotian river named Asopos, not the Peloponnesian river by the same name that originated in Phleious [[71-72]] (again, 2.5.2). Evidently Pausanias is associating a Corinthian myth about the Asopid Peirēnē with a composite Phliasian myth about the Asopids Corcyra, Aegina, and Thebe, not with the Theban myth about the Asopids Aegina and Thebe.

I should add that the Theban myth about the Asopid nymphs is more extensive than what we can see by simply comparing it with the corresponding Phliasian myth. Besides Aegina and the eponymous Thebe herself, other nymphs are included in a veritable Theban ensemble of Asopids. Most noteworthy is the nymph Antiope, described as the daughter of Asopos already in Homeric poetry (Odyssey xi 260): this Asopid figures as a virtual Mother Earth for the Thebans, since she is impregnated by Zeus and gives birth to the prototypical Thebans 
Amphion and Zethos (Odyssey xi 261-265). Also noteworthy are the Theban Asopid nymphs Ismene (Apollodorus 2.1.3) and Oëroe (Herodotus 9.51).

As for the Phliasian myth, the inclusion of the Asopid nymph Corcyra makes that myth more compatible with the Corinthian myth about the Asopid nymph named Peirēnē. The connection of the nymph Corcyra with the nymph Peirēnē is most apt, since the island city of Corcyra was the most eminent of all the daughter cities of the metropolis that was Corinth.

So far, I have been highlighting the Asopid nymph Peirēnē in her role as an otherworldly power who presides over the flow of fresh water from a spring located in the mountainous heights of the Acrocorinth all the way down to the city center of Corinth. As I have argued, the spring waters of Peirēnē emanate from the streams of a virtual Asopos, that is, from the otherworldly streams of a mighty river god whose waters flow underground until they surface at sacred places marked by either (1) springs in mountainous heights or (2) fountain houses in the centers of cities.

I submit that a parallel pattern of thinking is visible in the myth about the nymph named Samia, eponym of the island of Samos, who was known as a daughter of the river Maeander (Asios F 7 ed. Bernabé; via Pausanias 7.4.1). As we have seen, this river Maeander is notionally identical with the river Asopos in the making (Pausanias 2.5.2-3). As we have also seen, there are references to this virtual Asopos in the songs of both Ibycus (F 322) and Anacreon (F 448). $[[72-73]]$

In the case of the song of Anacreon, the wording of the testimony we find in Hesychius (A

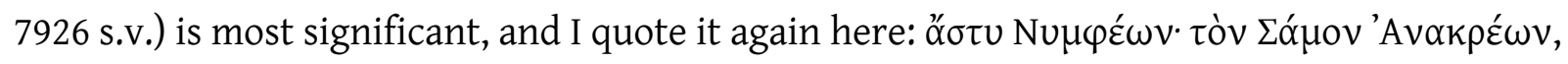

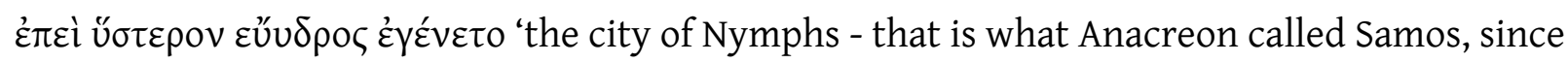
it became well-watered at a later time'. The reference here to 'a later time' has to do with the public works initiated in Samos by the dynasty of the tyrant Polycrates and his predecessors. 
Herodotus (3.60) says that the three greatest public works in the Greek-speaking world were located on the island of Samos: (1) a grand tunnel seven stadia in length, (2) a sea-wall protecting the harbor, and (3) the temple and precinct of the goddess Hera. Herodotus links all three of these public works with the dynasty represented by the tyrant Polycrates of Samos. And "it is impossible not to associate [these] three great works with the erga Polukrateia "public works of Polycrates' mentioned by Aristotle [Politics 5.1313b24]."65

Herodotus (again, 3.60) describes the grand tunnel of Samos as an orugma 'excavation' of spectacular proportions, designed by an architect from Megara named Eupalinos. It encased an underground aqueduct conveying the waters of a mountain spring all the way down to a fountain house located in the city center of Samos. "The tunnel leads through Mount Ampelos (modern Spiliani) from a spring to the north, emerging within the city walls, and was connected by a covered conduit with a fountain-house in the city (formerly Tigani, now Pythagoreion)." ${ }^{67}$

With regard to the building of the Samian underground aqueduct, I draw attention to "the Megarian connection," as suggested by the provenance of Eupalinos of Megara. In the city of Megara, Pausanias says, there existed a fountain house commissioned by Theagenes the tyrant of Megara (1.40.1), ${ }^{68}$ and this structure was supplied by waters flowing from the nearby mountains through an underground [[73-74]] aqueduct (1.41.2). ${ }^{69}$ The waters of the fountain house were sacred to nymphs called the Sithnides, and Pausanias reports a local myth that

\footnotetext{
${ }^{65}$ Barron 1964:213.

${ }^{66}$ On the archaeological background, see Privitera 1988:67n10. For more on the tunnel of Eupalinos, see Kienast 1995 and 2005; also Jantzen 2004.

${ }^{67}$ Barron 1964:214.

${ }^{68}$ Figueira 1985b:277.

${ }^{69}$ Figueira 1985a:145. On the archaeological background, see Privitera 1988:67n9. On the so-called Krene of Theagenes in Megara, see now also Hellner 2004, who argues that this surviving structure was built after 475 BCE and is therefore too late to be the original Krene of Theagenes.
} 
tells how one of these nymphs was impregnated by Zeus and gave birth to Megaros, eponymous hero of Megara (again, 1.40.1).

The relatively early dating for the rule of the tyrant Theagenes over the city state of Megara, around 650 to $625 \mathrm{BCE}$, has led historians to infer that the underground aqueduct of Megara was a model for the underground aqueduct of Samos - as also for the underground aqueduct of Athens, commissioned by the tyrant Peisistratos to supply a fountain house located in the city center and known by the name of Enneakrounos. ${ }^{70}$

There was a comparable fountain house located in the city center of Aegina, as we know

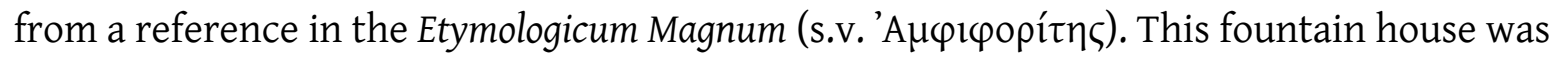
supplied by the waters of a spring that flowed down from the mountainous interior of the island through an underground aqueduct that extended all the way to the city center. In this instance, the aqueduct was a product of the combined forces of "nature" and "culture." That is, the natural pathways created over time by the course of the waters flowing down from the mountainous interior were enhanced by way of excavating artificial underground conduits to produce a continuum for the flow. ${ }^{71}$ I should add that this labor of excavating into the limestone infrastructure of the land is analogous, in mythological terms, to the imagined labor of ants excavating their own pathways in the same porous limestone infrastructure: it is as if the island's autochthonous Myrmidons or 'ant people' had built the pathway for the flow of the water. ${ }^{72}$ So, the [[74-75]] ancient waterworks of Aegina - both natural and artificial - are a

\footnotetext{
${ }^{70}$ Privitera 1988:66-67. See also Fearn 2007:103, especially n63. On the archaeological background, see Camp 1989:42-43; on the water systems of archaic Athens, see Tölle-Kastenbein 1994 and especially pp. 88 and following (with reference to possible vase depictions of the Enneakrounos).

${ }^{71}$ On the archaeological background, see Privitera 1988:65-67; also Fearn 2007:102-105.

${ }^{72}$ I refer again to the myth reported by Strabo $(8.6 .16$ C 375$)$ concerning the naming of the Aeginetans as Myrmidons: in this myth, the excavating habits of ants is a model for traditional practices of the Aeginetans in excavating their land. As I noted earlier, Strabo accepts as facts (1) the naming of the Aeginetans as Myrmidons and (2) the association of the Myrmidons with murmèkes 'ants'.
} 
fitting mythological monument for marking the primal deeds of the island's autochthonous Myrmidons.

There is actually a reference to this fountain house in Pindar's Nemean 3 (lines 1-5), where the neaniai 'young men' (line 5) who are about to perform this Aeginetan ode are pictured as waiting for the inspiration of the Muse as they stand 'at the waters of Asopos' (line 3-4: v̌ $\delta \alpha \tau$...

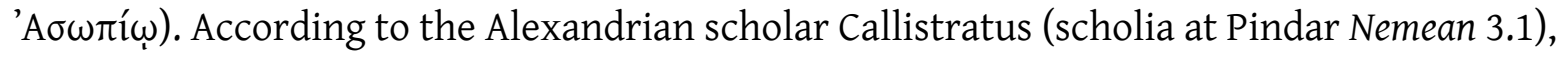
these waters are to be identified with a daughter of Asopos. ${ }^{73}$ Evidently, this Asopid is the

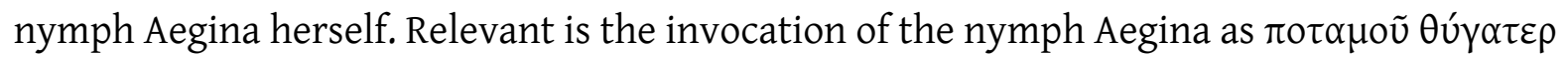
'daughter of the River' in an Aeginetan ode of Bacchylides (13.77), where the 'River' is none other than the god who is Asopos. ${ }^{74}$

In terms of the argumentation I have developed so far, I would add that these waters of the fountain house located in the city of Aegina are envisaged here as a continuation of the virtual Asopos.

\section{Asopos, Aegina, and the Aiakidai}

It remains to ask: what is the relevance of this virtual Asopos in Aegina to the Aiakidai as the native sons of Aegina? To formulate an answer, I return to the Hesiodic Catalogue.

Earlier, I argued that the Catalogue maintains an implicit mythological contract between Aegina and Thessaly with regard to the genealogy of the Aiakidai. Now I will argue that the Catalogue maintains a comparable contract between Aegina and Thebes. ${ }^{75}[[75-76]]$

In terms of this mythological contract, the state of Thebes accepts from the state of Aegina the Aeginetan nymph Aegina as a sister of the Theban nymph Thebe, that is, as an alternative

\footnotetext{
${ }^{73}$ Privitera 1988:64, 67; also Fearn 2007:102-105.

${ }^{74}$ On this reference to Aegina as daughter of Asopos in Bacchylides 13 (77), see Fearn 2007:116-117.

${ }^{75}$ Hall 2002:214 remarks that the mythological link between Thebe and Aegina does not mask the distinction between Aeolians and Dorians.
} 
daughter of the Theban river Asopos. Reciprocally, the state of Aegina accepts from the state of Thebes the river Asopos as the father of the Aeginetan nymph Aegina, since she is now a sister of the Theban nymph Thebe. This mythological contract is clearly recognized in the Aeginetan ode of Pindar to which I referred earlier, Isthmian 8. It is also recognized in an Aeginetan ode by Bacchylides (13) and in Pindar's Paean 6 (lines 134-137). ${ }^{76}$ And, as we have seen, this mythological contract is recognized even in the Phliasian ode of Bacchylides (9), despite the fact that this ode represents a Phliasian mythological view of the daughters of Asopos.

So, why can the state of Aegina accept the river Asopos from the state of Thebes? In terms of the mythological contract, it is because the state of Aegina already has its very own Asopos. It is a virtual Asopos - one that pushes up to the heights from underground in the land of the Aeginetans and then flows down to the fountain house in the center of the city. This same virtual Asopos can also push up from underground in the land of the Thebans - or even in the land of the Phliasians, for that matter.

We find explicit evidence for a mythological contract between the states of Aegina and Thebes in a narrative of Herodotus about a political and military alliance between these two states that dates back to a time when Aegina and Thebes made common cause against Athens (5.79-81) ${ }^{77}$ According to this narrative, the alliance was motivated by a response made to the Thebans by the oracle of Apollo at Delphi: in the words of the oracle, the Thebans were to choose as their allies a population that was genealogically ankhista 'closest' to them (5.79.1), and so they chose the Aeginetans as their ankhistees 'closest relatives' (5.80.2) ${ }^{78}$ Their choice was based on a myth that featured the nymphs Aegina and Thebe as twin daughters of the

\footnotetext{
${ }^{76}$ Fearn 2003:359; also 2007:88-95.

${ }^{77}$ For background, see Fearn 2007:88-95.

${ }^{78}$ Fearn 2003:359; also 2007:88-89.
} 
river god Asopos (5.80.1). In terms of this myth, the populations of [[76-77]] the states of Aegina and Thebes were descended from these sister nymphs.

In his narrative, Herodotus highlights a gesture made by the Aeginetans as a visible sign of their alliance with the Thebans. Planning military action against the Athenians, the Thebans asked the Aeginetans to send them reinforcements as a sign of their alliance. In response, the Aeginetans declared that they would send 'the Aiakidai' (5.80.2). We see here the actual involvement of 'the Aiakidai' as a visible sign of the alliance between the states of Aegina and Thebes. This sign, I argue, is relevant to what I have described as the mythological contract between these two states.

The narrative of Herodotus goes on to say that the Thebans, despite the presence of 'the Aiakidai', were defeated by the Athenians, and so they sent back 'the Aiakidai' to the Aeginetans and asked them to send andres 'men' instead (5.81). Then and only then did the Aeginetans launch military attacks against the Athenians (again, 5.81). The narrative here is contrasting this military action of the Aeginetans, which can be dated to $506 \mathrm{BCE}$, with the inaction of 'the Aiakidai' as notional reinforcements in the earlier military action of the Thebans against the Athenians.

I argue that 'the Aiakidai' that were present at that earlier event were an ensemble of contemporary Aeginetan aristocrats who were re-enacting, in stylized choral poses, the presence of their notional ancestors, the Aiakidai of the heroic age. In terms of this argument, there was a comparable re-enactment of the Aiakidai at the naval battle of Salamis as narrated by Herodotus (again, 8.64 and 8.83-84). ${ }^{79}$

Relevant is the use of the name Aiakidai in Pindar's Aeginetan odes with reference not only to the heroes descended from the local hero Aiakos but also to the contemporary aristocrats of

\footnotetext{
${ }^{79}$ This argument goes beyond what I say in Nagy 1990a:176-177 (6\$57). See also Nagy 2011 b.
} 
Aegina who claimed that they too were descended from Aiakos ${ }^{80}$ Also relevant is the juxtaposition of 'the Aiakidai' as hērōes 'heroes' with the andres 'men' of Aegina in the wording of Pindar's Pythian 8 (lines 27 and 28): in this Aeginetan ode, the prestige of 'the Aiakidai' (line 23) is realized by way of mentally associating the heroic with the human. [[77-78]] Such a mental association reflects what I described earlier as a sacralized metonymy.

With all its sacral pretensions, such a mental association can become the subject of ridicule if it fails in a moment of political or military crisis. That is what happens, I think, in the story told by Herodotus (5.81) about the ignominious defeat of the Thebans by the Athenians: seeing that 'the Aiakidai' that were sent to them by the Aeginetans were of no help, the Thebans sent them back to Aegina, asking the Aeginetans to send them andres 'men' instead.

\section{Conclusion}

From all we have seen, I conclude that the references to the Aiakidai and their Asopid mother Aegina in the Aeginetan odes of Pindar reflect an ideology that matches the ideology reflected by references to the Asopids in the epic composition known as the Hesiodic Catalogue of Women.

As I have emphasized all along, the ideology of the Catalogue can be traced back to Athens in the era of the Peisistratidai. But the question remains: why should there be any sharing of mythological references between Athens and Aegina in that preclassical era? The answer has to do with an insight achieved by Thomas Figueira: in the era of the Peisistratidai, there existed a political entente between Athens and Aegina - an entente that broke down only after

\footnotetext{
${ }^{80}$ Nagy 1990a:175-176, 178-179 (6§§56, 60).
} 
the expulsion of the tyrants from Athens ${ }^{81}$ I submit that the poetry of Pindar's Aeginetan odes represents a nostalgic reminiscence of that era of entente.

${ }^{81}$ Figueira 1993. 


\section{Bibliography}

Bakker, E. J. 1997. Poetry in Speech. Orality and Homeric Discourse. Ithaca NY.

Bakker, E. J. 2005. Pointing at the Past: From Formula to Performance in Homeric Poetics. Cambridge MA and Washington DC.

Barron, J. P. 1964. “The Sixth-Century Tyranny at Samos.” Classical Quarterly 14:211-229.

Baumann, H. 1936. Schöpfung und Urzeit des Menschen im Mythus der afrikanischen Völker. Berlin.

Burnett, A. P. 2005. Pindar's songs for young athletes of Aegina. Oxford.

Calame, C. 2007. "Mythos, musische Leistung und Ritual am Beispiel der melischen Dichtung." Literatur und Religion I. Wege zu einer mythisch-rituellen Poetik bei den Griechen (ed. A. Bierl, R. Lämmle, K. Wesselmann; Basiliensia - MythosEikonPoiesis, vol. 1.1) 179-210. Berlin / New York.

Camp, J. 1989. The Athenian Agora. Excavations in the Heart of Classical Athens. London.

Currie, B. 2005. Pindar and the Cult of Heroes. Oxford.

D’Alessio, G. B. 2004. “Textual Fluctuations and Cosmic Streams: Ocean and Achelōios.” Journal of Hellenic Studies 124:16-37.

D’Alessio, G. B. 2005a. “The Megalai Ehoiai: A survey of the fragments.” Hunter 2005a:176-216.

D’Alessio, G. B. 2005b. “Pindar, Bacchylides, and Hesiodic genealogical poetry.” Hunter 2005a: 217-238.

Davies, M. 1994. “The Tradition about the First Sacred War.” Hornblower 1994:193-212.

Fearn, D. 2003. "Mapping Phleious: Politics and myth-making in Bacchylides 9." Classical Quarterly 3:347-367.

Fearn, D. 2007. Bacchylides: Politics, Performance, Poetic Tradition. Oxford.

Figueira, T. J. 1981. Aegina, society and politics. New York.

Figueira, T. J. 1985a. "The Theognidea and Megarian Society.” Theognis of Megara: Poetry and the Polis (ed. T. J. Figueira and G. Nagy) 112-158. Baltimore MD.

Figueira, T. J. 1985b. "Chronological Table: Archaic Megara, 800-500 B.C." Theognis of Megara: Poetry and the Polis (ed. T. J. Figueira and G. Nagy) 261-303. Baltimore MD.

Figueira, T. J. 1991. Athens and Aigina in the age of imperial colonization. Baltimore. 
Figueira, T. J. 1993. Excursions in epichoric history: Aeginetan essays. Lanham MD.

Fowler, R. 1998. “Genealogical Thinking, Hesiod's Catalogue, and the Creation of the Hellenes." Proceedings of the Cambridge Philological Society 44:1-19.

Frazer, J. G. 1921. Apollodorus: The Library. I-II. London.

Hall, J. M. 1997. Ethnic Identity in Greek Antiquity. New York.

Hall, J. M. 2002. Hellenicity: Between Ethnicity and Culture. Chicago.

Hellner, N. 2004. “Die Krene von Megara.” Athener Mitteilungen 119:163-220.

Herda, A. 2006. "Panionion-Melia, Mykalessos-Mykale, Perseus und Medusa. Überlegungen zur Besiedlungsgeschichte der Mykale in der frühen Eisenzeit." Istanbuler Mitteilungen 56:43102.

Hirschberger, M. 2004. Gynaikôn Katalogos und Megalai Êhoiai. Ein Kommentar zu den Fragmenten zweier hesiodeischer Epen. Beiträge zur Altertumskunde. München / Leipzig.

Hornblower, S. 1994. ed. Greek Historiography. Oxford.

Hunter, R. 2005a. ed. The Hesiodic <<Catalogue of Women>>": Constructions and Reconstructions. Cambridge.

Hunter, R. 2005b. “The Hesiodic Catalogue and Hellenistic Poetry.” Hunter 2005:239-265.

Janko, R. 1982. Homer, Hesiod, and the Hymns: Diachronic Development of Epic Diction. Cambridge.

Jantzen, U. 2004. Die Wasserleitung des Eupalinos. Die Funde. Samos vol. 20. Bonn 2004.

Kienast, H. 1995. Die Wasserleitung des Eupalinos auf Samos. Samos vol. 19. Bonn.

Kienast, H. 2005. The Aqueduct of Eupalinos on Samos. Athens.

Kowalzig, B. 2007. Singing for the gods: Performances of myth and ritual in archaic and classical Greece. Oxford.

Larson, J. 2001. Greek Nymphs: Myth, Cult, Lore. Oxford.

Martin, R. P. 2004. "Home is the Hero: Deixis and Semantics in Pindar's Pythian 8." Arethusa 37:343-363.

Nagy, G. 1990a. Pindar's Homer: The Lyric Possession of an Epic Past. Baltimore.

Nagy, G. 1990b. Greek Mythology and Poetics. Ithaca NY.

Nagy, G. 2001. "Homère comme modèle classique pour la bibliothèque antique: les métaphores du corpus et du cosmos." Des Alexandries I. Du livre au texte (ed. L. Giard and Ch. Jacob) 149-161. Paris. 
Nagy, G. 2003. Homeric Responses. Austin TX.

Nagy, G. 2004a. Homer's Text and Language. Urbana and Chicago.

Nagy, G. 2004b. "L'aède épique en auteur: la tradition des Vies d'Homère." Identités d'auteur dans l'Antiquité et la tradition européenne (ed. C. Calame, and R. Chartier) 41-67. Grenoble.

Nagy, G. 2005a. “The Epic Hero.” A Companion to Ancient Epic (ed. J. M. Foley) 71-89. Oxford.

Nagy, G. 2005b. “The Epic Hero.”

http://chs.harvard.edu/publications.sec/online_print_books.ssp/gregory_nagy_the_epi c/bn_u_tei.xml_5

Nagy, G. 2008/2009. Homer the Classic. Cambridge MA and Washington DC. The 2008 online version is available at chs.harvard.edu. The 2009 printed version is distributed by Harvard University Press.

Nagy, G. 2009. "Hesiod and the Ancient Biographical Traditions." Brill Companion to Hesiod (ed. F. Montanari, A. Rengakos, and Ch. Tsagalis) 271-311. Leiden.

Nagy, G. 2009/2010. Homer the Preclassic. Berkeley and Los Angeles CA. The 2009 online version is available at chs.harvard.edu. The 2010 printed version is published by the University of California Press.

Nagy, G. 2011b. "A second look at the poetics of re-enactment in Ode 13 of Bacchylides." Archaic and Classical Greek Song (ed. L. Athanassaki and E. L. Bowie). Berlin.

Pfeijffer, I. L. 1999. Three Aeginetan odes of Pindar : a commentary on Nemean V, Nemean III and Pythian VIII. Leiden.

Privitera, G. A. 1988. “Pindaro, Nem. III 1-5, e l'acqua di Egina.” Quaderni Urbinati di Cultura Classica 88:63-70.

Robertson, N. 1978. "The Myth of the First Sacred War.” Classical Quarterly 28:38-73.

Rutherford, I. 2005. "Mestra at Athens.” Hunter 2005a:99-117. 
Tölle-Kastenbein, R. 1994. Das archaische Wasserleitungsnetz für Athen und seine späteren Bauphasen. Mainz.

Wagner, R. 1984. ed. 2nd ed. 1926. Apollodorus: Bibliotheke. Leipzig.

West, M. L. 1985. The Hesiodic Catalogue of Women. Oxford. 